\title{
Self-esteem people with HIV/AIDS: Review of reality counseling approach
}

\author{
Anis Lud Fiana* \\ Universitas Negeri Semarang, Semarang, Indonesia \\ Email: anislud22@students.unnes.ac.id
}

\begin{abstract}
Purpose - The purpose of this study was to determine the self-esteem of people with HIV/AIDS in terms of the reality counseling approach.

Method - The method used in this paper is a literature study.

Result - The results of this study indicated that the reality counseling approach with the wants, needs, and perceptions, direction and doing, self-evaluation, and planning (WDEP) technique could help their circumstances and situations assess more realistically, help reduce the burden on thoughts, help find meaning in their lives, help have a life expectancy, and maintain or increase the self-esteem of people with HIV/AIDS.

Implications - The results of this study expected to provide benefits in scientific guidance and counseling considering that in terms of applicability, the reality approach can be used for various problems in counseling practice.

Originality-In this paper, a reality counseling approach can be one way as a form of mental support. People with HIV/AIDS needs the help of others in going through its downtime in achieving the self-esteem that ultimately reaches the meaning of his life.
\end{abstract}

Keywords: Self-esteem, HIV/AIDS, reality therapy, reality counseling.

For citation: Fiana, A. L. (2020). Self-esteem people with HIV/AIDS: Review of reality counseling approach. Journal of Advanced Guidance and Counseling. 1(2). 121-139. https://doi.org/10.21580/jagc.2020.1.2.5941.

*Corresponding author: Anis Lud Fiana (anislud22@students.unnes.ac.id), Universitas Negeri Semarang, Sekaran, Gunung Pati, Semarang City, Central Java 50229.

Journal of Advanced Guidance and Counseling - Vol. 1 No. 2 (2020) 
Anis Lud Fiana

JAGC | 122

\begin{abstract}
Abstrak
Tujuan - Tujuan penelitian ini adalah untuk mengetahui harga diri orang dengan HIV/AIDS (ODHA) ditinjau dari pendekatan konseling realitas.

Metode - Metode yang digunakan dalam penulisan ini adalah studi literatur.

Hasil - Hasil penelitian ini menunjukkan bahwa pendekatan konseling realitas dengan teknik wants, needs, and perceptions, direction and doing, selfevaluation, and planning (WDEP) dapat membantu menilai keadaan dan situasi mereka secara lebih realistis, membantu mengurangi beban pikiran, membantu menemukan makna dalam hidup mereka, membantu memiliki harapan hidup, dan mempertahankan atau meningkatkan harga diri ODHA.

Implikasi - Hasil penelitian ini diharapkan dapat memberikan manfaat dalam bidang bimbingan dan konseling, pendekatan realitas dapat digunakan untuk berbagai permasalahan dalam praktik konseling.

Orisinalitas - Dalam tulisan ini, pendekatan konseling realitas dapat dijadikan salah satu bentuk dukungan mental. ODHA membutuhkan bantuan orang lain dalam menjalani masa henti dalam mencapai harga diri yang pada akhirnya mencapai makna hidupnya.
\end{abstract}

Kata kunci: Harga diri, HIV/AIDS, orang dengan HIV AIDS, terapi realita, konseling realita.

\title{
Introduction
}

HIV/AIDS case is a global health issue including in Indonesia. People with HIV/AIDS are referred to as individuals infected with HIV (Human Immunodeficiency Virus). The virus attacks white blood cells so it can damage the human immune system which ultimately cannot survive the disease disorder. Without the immunity system then when diseases attack the body, the body has no protection. HIV can weaken the immune system from the ovaries, or hosts-. This condition, if we leave it without treatment, it will cause AIDS (Acquired Immunodeficiency Syndrome). HIV remains there for life, even after undergoing treatment. In a period of about 10 to 12 years, HIV can cause AIDS (Acquired Immunodeficiency Syndrome).

Based on data from World Health Organization (WHO), to date, no cure for HIV has been found, but people with HIV/AIDS can control the development, and prevent the spread of HIV through Antiretroviral Therapy, or ART (WHO, 2017). ART includes administering the antiretroviral (ARV) drug that serves to disrupt the 
life cycle of HIV, as well as preventing the virus from replicating itself (Aidsinfo, 2017). people with HIV/AIDS to survive needs to take ARV medication every day. This will help control the virus and slow down the effects on the body. The drug does not cure as a whole but can reduce the number of viruses in the body meaning the virus no longer replicates itself.

People with HIV/AIDS usually experiences psychological crises in itself in the form of panic, fear, anxiety, despair, depression, insecurity, and poor coping. According to Feifel \& Nagy in Ahdiany (2017) One of the psychological impacts experienced after learning HIV positive status, a person will be more likely to experience anxiety about death. In addition, they get bad or negative views that arise because seeing HIV/AIDS can occur in groups that have different behaviors for most communities. The views gained from society occur when the general public agrees with a person's bad stereotypes, such as mental illness, addicts. A perspective that assesses negatively on oneself becomes a consequence that can worsen their immune function, which if not immediately handled properly.

In social and societal life, people with HIV/AIDS tends to get bad views and social punishments from society in a variety of ways. Similar to the research from Baroya (2017) stated that a majority of $81.4 \%$ of respondents stated that they were not willing to buy food if they knew the seller was HIV positive. Furthermore, it is known that as many as $75 \%$ have concerns about being infected with HIV by means of saliva contact with people with HIV/AIDS. This is often associated with negative behaviors of homosexuality, bisexuality, prostitution, high-risk groups that are groups that do not use safeguards (condoms) in sex, and changing partners. Injecting drug users are also one of the groups at risk of contracting HIV / AIDS (Sumini, 2017). In fact, people living with HIV/AIDS may not be infected at all through this negative behavior, but from blood transfusions from HIV positive or from their partners.

People with HIV/AIDS tends to have weak and helpless conditions both physical, psychic, and social. Besides physical problems, there are still psychological, social, and economic problems that do not get attention from the community can certainly affect the life of people with HIV/AIDS itself (Dejman, 
Anis Lud Fiana

2015). As a result of declining physical, psychic, and social conditions will certainly affect the quality of life they live. When people with HIV/AIDS first learned that he was HIV positive, various psychological, mental, and economic problems arose. In JAGC | 124 accordance with Karamouzian's opinion (2015) that differences in treatment, views, and discrimination from the family environment, society, and even health workers have a social impact on people with HIV/AIDS and can indirectly affect the psychological and economic impact of people with HIV/AIDS. This situation can cause stress, despair, and feel that no one accepts him as he is. This social impact can affect her confidence, her self-esteem becoming low, and losing the meaning of her life.

Irreversible conditions, such as illness or the reality of life on HIV-positive status, the injustice of people's views, and suffering can lead to despair, depression, suicide, and loss of hope that can give individuals a great opportunity to discover the meaning of life. Meaning life becomes one of the solutions in maintaining the welfare of life so that the physical condition is stable. The meaning of life is considered important to provide value. The delusion of life owned and felt will affect the sense of optimism of people with HIV/AIDS (Burhan, 2014). The meaning of life is also personal and unique because individuals are free to decide their own way of finding and adapting the meaning of life.

In addition to meaning life, self-esteem is important to protect yourself from stress and depression. This is in accordance with people with HIV/AIDS need to maintain psychic stability to maintain the immune system that is the main capital (biologically) for them to survive. Simply self-esteem can be defined as people's feelings about themselves related to the importance of achievement, positive interpersonal relationships, and psychological well-being (Vohs \& Baumeister, 2016). Self-esteem is formed through individual interaction with the environment. According to Maslow, self-esteem is a necessity that must be met by man (Rohmah, 2012).

This is reinforced by the results of Hidayanti research (2018) stated that in the face of psychological problems such as low self-esteem, people with HIV/AIDS desperately needs social support from spouses, parents, children, friends, 
counselors, and health teams. Furthermore, there are three sources of living meaning. They are creative values, values of attitude, and value of experience. Furthermore, Limalvin's research (2020) states that spiritual support and peer groups of fellow people with HIV/AIDS can ease the burden of one's thoughts.

Based on the above statement indicates that the psychic condition in people with HIV/AIDS needs to be considered to maintain their health. An approach to counseling can be one way as a form of mental support. people with HIV/AIDS needs the help of others in going through its downtime in achieving the self-esteem that ultimately reaches the meaning of his life. Reality therapy is one of the approaches to counseling that can be applied to people with HIV/AIDS special counseling. This is because people with HIV/AIDS with various problems requires intervention to maintain its self-confidence. Fall reality theory (2017) directs an individual to behave like a healthy person to meet his needs based on the principles of responsibility (responsibility), reality (reality), and norm (right).

Reality therapy states that human learning is a lifelong process based on choice. Reality counseling is built on the assumption that humans are selfdetermining agents (Corey, 2017). The individual has the right to choose how he or she will think and act. This approach also tends to be simple, so it can be applied to a variety of situations, including people with HIV/AIDS -specific counseling. From some of the above statements, researchers are interested in reviewing "How to Esteem People with HIV/AIDS: Review Of Reality Counseling Approach?"

\section{Research Method}

This research is a model of conceptual articles. Jonker (2011) states that theoretical concepts used in building conceptual models can provide perspectives or a way of looking at empirical phenomena. This qualitative research library study collects all information from research objects such as books, journals, or articles that support the entire research process (Chang, 2014). Various information is needed about people with HIV/AIDS self-esteem picture and reality counseling approach. Data validity techniques using source triangulation and analyzed using Hiberman and Milles interaction analysis models (llyas, 2016) 
Anis Lud Fiana

\section{Results and Discussion}

\section{Self-Esteem Concept}

Self-esteem becomes one of the important aspects of one's personal JAGC $\mid 126$ formation. Self-esteem begins to exist from birth and will continue to form by interacting with its environment (Refnadi, 2018). If one cannot appreciate himself then it will be difficult to appreciate the people around him. Baron and Byrne in Srisayekti (2015) stated that self-esteem is a self-evaluation that individuals make against him in the range of positive to negative. Those with low self-esteem are prone to depression, psychosomatic disorders, tend to be harsh and stressful. High self-esteem reflects a positive person and a good attitude in interacting with others. As self-esteem begins to form from social processes in its environment.

Farnoodian (2016) states that self-esteem is a value that has self-concept information derived from personal beliefs about all the traits and characteristics that exist within him. One's self-esteem can be seen from how judging about him, this will affect behavior in daily life. The process of developing self-esteem starts from family relationships and the influence of the wider community so that the individual can determine the direction of his own destiny (Nikmarijal, 2014). These individual judgments are expressed in attitudes that can be high and negative. According to Maslow in Larasati (2012), there are two forms of need for selfesteem namely a weak and strong form. As for what is included in the form of weak needs namely the need for appreciation from others, the need for social status, glory, honor, attention, reputation, appreciation, and dominance. While the form of strong needs is the need for confidence, success, competence, and freedom.

Self-esteem refers to one's evaluation of himself both positive and negative and can consider himself valuable (Prawesti, 2016). According to Velasco (2013) stated that self-esteem is one of the dimensions that can affect self-disclosure. as for the characteristics of self-esteem according to Larasati (2012) namely the characteristics of individuals who have high self-esteem, namely (1) Feeling satisfied and proud to be themselves, (2) More often experience pleasure and happiness, (3) Respond to praise and criticism as input, (4) Be able to accept failure 
and rise immediately, (5) Respond to new challenges with enthusiasm, (6) Accept negative events that occur in the self and try to correct them, and (7) Think positively and conclusively.

As for the characteristics of individuals with low self-esteem, namely (1) Feeling dissatisfied with him, (2) Wanting to be someone else, or be in someone else's position, (3) More often experiencing negative emotions such as sadness, stress, and anger. (4) Unable to receive praise but still annoyed by other people's criticism (5) It is difficult to accept failure even experience excessive disappointment when finding failure. (6) Tend to be pessimistic young and view various events in life as negative, (7) Avoid risk, (8) Be negative (cynical) in others or institutions associated with him, and (9) Think that is not constructive or constructive (feel unable to help himself).

Based on the above statement it can be concluded that self-esteem is a selfassessment or feeling of self-worth towards something that has been done can be concluded that self-esteem is a self-assessment or feeling of self-worth towards something that has been done. This characteristic of avid who has low self-esteem is more likely to feel that he or she is incapable and worthless, less likely to dare to face new challenges in his life, and less likely to be sure of the thoughts and feelings he or she has, as well as individuals who have high self-esteem will feel satisfied with his life and more often feel happy.

\section{Approach to Counseling Reality}

The reality counseling approach believes that a person's actions are the result of his or her own choices. The concept of reality is associated with appropriate or inappropriate behavior. Reality counseling is built on the assumption that humans are self-determining agents (Corey, 2017). This is called a choice theory. In this perspective, choice theory teaches that each individual essentially always chooses every action he or she does, and the real individual always has control over each of his choices (Corey, 2017). The implication of choice is the consequences. Penalties in reality counseling are not enforced as a behavior-altering technique. Glasser 
Anis Lud Fiana

recommends that he not be punished in any form and allowed to learn to have reasonable consequences from his own equipment (Latipun, 2010).

The reality counseling approach is focused on behavior now. This approach JAGC | 128 aims to help counselee deal with reality and meet basic needs without harming themselves or others. Corey (2017) explains that the underlying characteristics of the reality approach are (1) Emphasize choice and responsibility, i.e. dealing with people "as if" they had a choice. Counselors focus on areas where clients have a choice, to do so getting them closer to the people they need. For example, engaging in meaningful activities, such as work, is a good way to earn respect from others, and work can help counselee meet their need for power. (2) Reject transference, counselors strive to be themselves in their professional work. By being themselves, counselors can use relationships to teach counselors how to relate to others in their lives. Glasser argues that transference is good way counselors and counselee avoids being who they are and having what they do now.

Furthermore, (3) Focus counseling on the present, the approach of reality does not really reject the past. If the counselee wants to talk about past successes or good relationships in the past, counselors will listen because this can be repeated in the present. Counselors will give sufficient time for past failures and will reassure counselee that counselors do not reject them. The counselor will immediately tell the counselee that "What happened in the past cannot be changed". So the more time spent looking back, the more evasive it was to look ahead. (4) Avoid focusing on symptoms or problems, Glasser states that almost all symptoms are caused by a happy relationship. By focusing on this issue, especially interpersonal concerns, therapy can generally be shortened. (5) The traditional view of mental illness, the theory of choice rejects the traditional idea that people with problematic physical and psychological symptoms are called mentally ill. Glasser in Correy challenges the traditionally accepted view of mental illness and treatment using drugs, especially the widespread use of psychiatric drugs that often result in negative side effects both physically and psychologically.

The key concept of reality theory according to Corey (2017), namely (1) The theory of choice (choice theory), man has the ability to change and change it comes 
from himself, not because of the strength and drive of the environment or other forces beyond himself, (2) Basic needs, that is; survival or self-preservation, love and belonging, power or inner control, freedom or independence, fun or enjoyment, (3) Total behavior, which consists of four inseparable components. The four total behaviors are actions, thoughts, feelings, and physiologically. Doing total behavior can help the individual to achieve a fulfillment of basic needs, (4) A quality world (quality world), a quality world is a coveted world. This part of the process of reality therapy is to assist clients in prioritizing their desires and uncovering what is most important to them, and (5) The characteristics of reality therapy, i.e. emphasize choices and responsibilities; reject transference; focus therapy on the present moment; avoid focusing on symptoms or problems; traditional view of the mentally ill.

Glasser stresses that the only behavior of someone we can control is our own behavior, which means the best way to control the events around us is through what we do. (Corey, 2017). The focus of reality therapy is on what the client realizes and then helps them raise their level of awareness. Once they become aware of how ineffective their behavior is to control the world, they will be more open to learning alternatives to how to behave. There are several characteristics of the relationship between the counselor and the counselee, namely the need for mutual involvement between the counselor and the counselee, the interconnectedness can be known and understood from the mutual understanding, mutual contact, mutual sympathy. Mutual care is the key to achieving success in counseling.

In general, the goal of the reality counseling approach is for individuals to achieve a life with success identity (Corey, 2017). Then the individual must be responsible, namely having the ability to achieve satisfaction with his personal needs. Reality counseling is an approach based on the assumption that there is a psychological need throughout his life that is the need to feel unique, distinctive, separate, and different from others. The need for self-identity is a driver of behavioral dynamics amid universal cultures. 
Anis Lud Fiana

Counselee's personal qualities become the purpose of reality counseling which is to be an individual who understands his real world and must meet his needs. Although looking at the world of reality between one individual and another can be different but that reality can be obtained by comparing it with others. Therefore, the counseling process is tasked with helping counsel to meet its needs with $3 R$ i.e. right, responsibility, and reality.

Wubbolding in Fall (2017) states to describe the process in which a counselor challenges and encourages the counselee to make new and better choices by using a reality therapy technique called "WDEP". The WDEP system is $W=$ wants, needs, and perceptions; $D=$ direction and doing; $E=$ self-evaluation; and $P=$ planning. The more reality therapy, the more counselee can connect with people, the greater their chances of having a happy experience. WDEP technique is a technique in the form of focusing on questions that lead to answers in self-assessing, desire, behavior, and making plans to achieve a goal. So it can be concluded that reality counseling with the WDEP technique is a counseling process that leads to desires, self-evaluation, and plans to make it happen.

\section{People with HIV/AIDS Self-Esteem Reviewed from Reality Counseling Approach}

HIV/AIDS positive individuals will experience some life changes. When a person is first infected with HIV, most of them will show his psychosocial changes such as living in depression, stress, feeling alone, feeling no social support, and a behavior change (Burhan, 2014). Stress and depression will certainly affect the health of people with HIV/AIDS, that stress can improve the development process of the HIV/AIDS virus. So to avoid that, people with HIV/AIDS should be able to reduce its stress levels by adjusting and accepting its condition.

people with HIV/AIDS tends to have weak and helpless conditions both physical, psychic, and social. This will certainly affect his quality of life. Physical and psychic changes can have an impact on his psychological life such as embarrassment and loss of confidence. Bastaman in Burhan (2014) said that the emotional changes experienced by people with HIV/AIDS will lead to rejection 
(denial) when a diagnosis, anger (anger), offers (bargaining), and depression (depression), which then, in the end, the patient must accept reality (acceptance). Another frequent impact of people with HIV/AIDS is excessive stress and even attempted suicide (Rosenfeld, 2015).

Basically, counseling is aimed at people who have difficulty in education, JAGC | 131 employment, and social issues where the situation cannot be chosen and cannot decide for themselves (Prayitno, 2013). people with HIV/AIDS counseling services are performed by experts (counselors, psychologists, trained health workers) to people with HIV/AIDS who are blind to assistance. people with HIV/AIDS special counselors have a slightly different role than common, as counselors are required to be active and directed in crisis situations.

Counseling as a form of professional assistance helps counselee to explore academic, personal, and health issues (Yusuf, 2016). people with HIV/AIDS requires access to counseling to obtain guidance in improving quality of life, self-esteem associated with individual confidence. Guidance has meaning as a guide, a giver, and leads individuals in a better direction than ever before (Hidayanti, 2015). One approach to counseling that can be used is the realistic approach. This therapy emphasizes that counseling consists of helping the counselor to learn about ways to regain control of his life and to live a more effective life. Counseling is needed to help manage the problems faced by counselee (Hikmawati, 2012).

people with HIV/AIDS special counseling aims to reduce depression, stress, self-acceptance, and increase self-esteem. Specific means typical, unique and unusual (KBBI, 2016). According to Hidayanti (2017) in his research stated that the hospital that became the referral center for people with HIV/AIDS formed a peer support group. These mentoring activities include group guidance and peer counseling providing opportunities to exchange experiences, this activity can increase people with HIV/AIDS self-esteem. Basically, the function of guidance and counseling is as a facilitator and motivator so that the counselee can solve the problem.

Reality theory believes that each individual has strength in health or growth. Basically, people want to be satisfied and enjoy an identity of success, show 
responsible behavior and have meaningful interpersonal relationships. Relevant to the condition, Corey and Wubboding in Mulawarman (2012) states that reality counseling can help individuals to control behavior and encourage individuals to emphasize choice and have hope. The fact of reality counseling is that looking at individuals always has psychological needs throughout life (Corey, 2013). The focus of this reality counseling is what the counsel realizes which will then raise his level of awareness to realize the effective and ineffective behavior of the individual.

Reality counseling considers that each individual has five basic needs (power and achievement, love and belonging, freedom, fun, survival) and the individual will experience problems if his needs are not met (Capuzzi \& Stauffer, 2016). The reality counseling approach uses the WDEP system as a technique in the counseling process. The implementation of interventions in this study refers to the procedure of reality counseling approach with WDEP techniques presented by Glasser in Corey (2017) namely want, direction or doing, evaluation, and planning. The problems in meeting the basic needs of life found in people with HIV/AIDS include confidence, self-meaning, stress, fear, anxiety, and loss of self-esteem. Questions in the process of reality counseling have an important role in exploring themselves over total behavior (total behavior), evaluating plans, and shaping new behaviors (Mulawarman, 2020).

The approach of reality counseling with WDEP techniques can be applied as one of the efforts in maintaining and improving people with HIV/AIDS self-esteem. Evolving communication helps improve in the face of stress and decision-making attached to HIV status (Saam, 2014). Questions in the counseling process are useful for counselors to enter the inner world of the counselee, making it easier to gather information and help the counselee control her life. The counseling phase starts at the question, i.e. $W=$ wants, needs, and perceptions mean that reality therapists help counsel in finding their desires and hopes. The question that can be given is "What do you want and expect after knowing HIV positive status?". At this stage identify the desire, hope in life. Through this question, counsel is helped to gain confidence and identify desires and expectations. 
The second stage, namely $D$ (direction and doing), focuses on the moment is marked by the key question "What are you doing to achieve your wishes? if you do your activities now, where will your life be?". At this stage, counsel is asked to explain the conduct carried out in relation to meeting its expectations. Through this question, counsel can stimulate themselves in controlling and controlling themselves in relation to people with HIV/AIDS self-esteem.

In the next stage, namely E (self-evaluation), self-evaluation is the foundation of the reality therapy procedure. "Searching and fearless self-evaluation is the way to change behavior". Counsel was asked to evaluate herself through the question "Does behavior now have a reasonable chance of getting what you want for a better life? Can what you do today help you achieve your life expectancy?". Of all WDEP procedures, the evaluation stage becomes the most core and important procedure that is at the stage of self-evaluation. At this stage, the counselor helps the counselor to conduct an assessment of him, helping to see the extent effectiveness of the conduct of the counselee in the process of achieving his needs. Once the individual is able to evaluate himself then the hope is that the counselee has greater control over his own life, able to make better choices later, involving counselee examining the direction of behavior, new direction, and plan.

Furthermore, in the last stage, namely $\mathrm{P}$ (planning), a lot of significant work of the counseling process involves helping clients identify specific ways to meet their desires and needs. Once the counselee determines what it wants to achieve, the counselor helps the counselee to make a responsible behavior change plan to achieve his or her goals. They are generally prepared to explore other behaviors that might formulate a new action plan. The key question is, 'What's your plan?' At this stage people with HIV/AIDS after being able to gain confidence and self-esteem is expected to be able to make behavioral changes that lead to maintenance and increase people with HIV/AIDS self-esteem. Also, it is expected to have high selfesteem in controlling more effective behavior. Reality counseling believes that changes in counsel's life occur only if the counsel itself wants to change its behavior (Sharf, 2012). 
Anis Lud Fiana

The reality counseling approach brings people with HIV/AIDS to identify her desires, help think about behavioral steps, evaluate herself, and plan the direction of her life goals. In addition, this technique invites the counselee to imagine the JAGC | 134 expectations that want to be achieved, to meet his needs. The main focus of reality counseling is to help the counselee take responsibility for its choices and find better ways of meeting its needs (Mulawarman, 2020). In this case, reality counseling helps people with HIV/AIDS to know the way of life, the behavior that wants to be changed towards positivity, so that the realization of high self-esteem for the return of confidence to move on.

Questions on the reality counseling process aim to explore total behavior, evaluate plans, and shape new behaviors according to what the counselee really wants and needs. Schoo \& Schoo in Gabriella (2012) states that reality counseling helps people with chronic diseases take responsibility for the choices taken in their health-related life, and helps counselee choose and maintain a healthier lifestyle for her. This was reinforced by Oktavia's research (2016) that reality therapy is effective in improving its psychic health and also restoring people with HIV/AIDS optimism. This counseling allows people with HIV/AIDS to express itself and teach to deal with negative feelings as well as exercise the ability to control what is perceived (Farmani, 2015).

Wubbolding in Mulawarman (2020) states that behavior may change when counselors can apply the following principles: (1) current-oriented, (2) emphasis on choice, (3) control of actions, and (4) the importance of relationships. This is already in question in the WDEP system, that the question has already led to the current situation, leading to the desired choice by the counselee. This approach refers to the rational process of current or current behavior (Komalasari, 2011). Similarly, relationships during counseling sessions are one of the factors of effective behavior change. Reality counseling services are used to assist people with HIV/AIDS in interpreting life goals and fulfilling identity needs related to people with HIV/AIDS self-esteem.

Counseling with a realistic approach to people with HIV/AIDS is expected to help them assess their situation more realistically. Reality counseling is a process of 
communication between counselors and counselee about the choices that will be taken in meeting her life needs (Febrianto, 2019). This reality approach with the goal of counselee has realistic actions and feels strongest to be able to choose and behave for the achievements of life they crave.

Approaching reality counseling with the WDEP system, counselors look at an JAGC | 135 individual in the sense of whether or not his behavior is appropriate to practical reality, social reality, and moral reality. Related to people with HIV/AIDS the purpose of applying this WDEP technique to help the counselee to accept its HIVinfected reality. Reality counseling teaches the counselee to take responsibility for his choices (Jusoh, 2015). In addition, counselors assist counselee in reducing stress, helping to find their desires, actions, thoughts, feelings, specific, meticulous, and unique information, further helping the counselee to evaluate themselves, and the latter invites the counselee to be able to make plans to achieve its needs with high self-esteem.

One's self-esteem can be seen from self-attitude and considers itself valuable as an individual, hence the WDEP technique refers to questions that lead to hope. So when a person feels meaningful and valuable then that person has great hope to move on with his life. from here it can be known that an people with HIV/AIDS who has a high level of self-esteem will trust himself to have dreams, hopes, and a coveted world.

From the above statement, it is concluded that people with HIV/AIDS requires counseling to help reduce the burden of the mind, help find the meaning of his life, and restore or increase the self-esteem. The purpose of using WDEP techniques for people with HIV/AIDS can be to monitor facts on its own related to self-esteem, thus encouraging people with HIV/AIDS to have a life expectancy.

\section{Conclusion}

People with HIV/AIDS tend to have helpless conditions both physically, psychically, and socially. The consequences of declining physical, psychic, and social conditions will certainly affect his quality of life. people with HIV/AIDS requires access to counseling to obtain guidance in improving quality of life, self-esteem 
Anis Lud Fiana

associated with individual confidence. One approach to counseling that can be used is the realistic approach. This therapy emphasizes that counseling consists of helping the counselor to learn about ways to regain control of his life and to live a more effective life.

From this article, it is worth considering for people with HIV/AIDS and counselors to be able to apply several approaches of counseling, one of which is the approach of counseling reality therapy. For researchers can then consider other variables for treatment to people with HIV/AIDS such as person-centered approach, CBT, existential-humanistic, and other counseling approaches. The results of this study are expected to provide benefits in guidance and counseling research given that in terms of applicability, the reality approach can be used by counselors in various forms of counselee problems in the counseling process.

\section{References}

Ahdiany, G, N. Widianti, E. \& Fitria, N. (2017). Tingkat kecemasan terhadap kematian pada ODHA. Jurnal Keperawatan Soedirman (The Soedirman Journal of Nursing), 12(3). http://dx.doi.org/10.20884/1.jks.2017.12.3.758.

AIDSinfo. (2017). The HIV life cycle. Diunduh dari: https://aidsinfo.nih.gov/understanding-hiv-aids/factsheets/19/73/the-hiv-life-cyle.

Baroya, N. (2017). Prediktor sikap stigma dan diskriminasi terhadap orang dengan HIV dan AIDS di kabupaten Jember. Jurnal IKESMA. Vol. 13 No. 2. https://doi.org/10.19184/ikesma.v13i2.7032.

Burhan, R. Fouriana. Zuhroni. (2014). Gambaran kebermaknaan hidup orang dengan HIV/AIDS (ODHA) serta tinjauannya menurut Islam. Jurnal Psikogenesis. 2(2). https://doi.org/10.24854/jps.v2i2.46.

Capuzzi, D., \& Stauffer, M, D. (2016). Counseling and psychoterapy: theories and intervention (sixth Edition). USA: American Counseling Association.

Chang, W. (2014). Metodologi penulisan ilmiah. Jakarta: Penerbit Erlangga.

Corey, G. (2013). Teori dan praktek konseling dan psikoterapi. Bandung: Refika Aditama. 
Corey, G. (2017). Theory and practice of counseling an psychotherapy (10th edition). California: Brooks/Cole.

Dejman, M, Ardakani HM, Malekafzali B, Moradi G, Gouya MM, Shushtari ZJ, et al. (2015). Psychological, social, and familial problems of people living with HIV/AIDS in Iran: A qualitative study. International Journal of Preventive Medicine. 6(1). DOI: 10.4103/2008-7802.172540.

Fall, K. A., Holden, J. M., \& Marquis, A. (2017). Theoretical models of counseling and psychotherapy. Taylor \& Francis.

Farmani, F., Taghavi, H., Fatemi, A., \& Safavi, S. (2015). The efficacy of group reality therapy on reducing stress, anxiety and depression in patients with multiple sclerosis (MS). Behavioral Research Center of SBMU.

Farnoodian, P. (2016). The effectiveness of group reality therapy on mental health and self-esteem of students. International Journal of Medical Research \& Health Sciences. 5, 9S:18-24. https://www.ijmrhs.com/abstract/theeffectiveness-of-group-reality-therapy-on-mental-health-and-selfesteemof-students-3866.html.

Febrianto, B., \& Ambarini, Tri, K. (2019). Efektivitas konseling kelompok realita untuk menurunkan kecemasan pada klien pemasyarakatan. Jurnal IImiah Psikologi Terapan. 7(1). https://doi.org/10.22219/jipt.v7i1.7838.

Gabriella, A. (2012). Gambaran konseling berbasis reality therapy pada pria HIVpositif yang belum membua status kepada istri. Jurnal Perkotaan. 4(2). http://ojs.atmajaya.ac.id/index.php/dululppm/article/view/227.

Hidayanti, E. (2018). Implementasi bimbingan dan konseling untuk meningkatkan self esteem pasien penyakit terminal di kelompok dukungan sebaya (KDS) RSUP. Dr. Kariadi Semarang. Jurnal Ilmu Dakwah. 38(1). DOI : 10.21580/iid.v38.1.3970.

Hidayanti, Ema. (2015). Dasar-dasar bimbingan rohani pasien. Semarang: Karaya Abadi Jaya.

Hikmawati, F. (2012). Bimbingan konseling edisi revisi. Jakarta: Rajawali Pers.

Ilyas. (2016). Pendidikan karakter melalui homeschooling, Journal of Nonformal Education. 2 (1). https://doi.org/10.15294/ine.v2i1.5316.

Jonker, J., Pennink, Bartjan J.W., Wahyuni, Sari. (2011). Metodologi penelitian: panduan untuk master Ph.D di bidang manajemen. Jakarta : Salemba Empat. 
Anis Lud Fiana

Jusoh, A. J., \& Hussain, S. P. (2015). Choice theory and reality therapy (CTRT) group counseling module. Asian Journal of Humanities and Social Studies, 3(4). Retrieved from https://www.ajouronline.com/index.php/AJHSS/article/view/2961.

JAGC | 138 Karamouzian, M,. Akbari, M., Haghdoost. A-A., Setayesh, H., Zolala, F. (2015). "I am dead to them": HIV-related stigma experienced by people living with HIV in Kerman, Iran. Journal Association of Nurses AIDS Care. 26(4);46-56. DOI: 10.1016/i.jana.2014.04.005.

KBBI. (2016). Kamus besar bahasa Indonesia. Jakarta: Gramedia Pustaka Utama.

Komalasari, G. (2011). Teori dan teknik konseling, Jakarta Barat: PT INDEKS.

Larasati, W.P. (2012). Meningkatkan self esteem melalui metode self-instruction. (Thesis). Fakultas Psikologi Program Studi Psikologi Pendidikan Universitas Indonesia, Jakarta.

Latipun. (2010). Psikologi konseling. Malang: UMM Press.

Limalvin, N. P., Putri, W. C. W. S., \& Sari, K. A. K. (2020). Gambaran dampak psikologis, sosial dan ekonomi pada ODHA di Yayasan Spirit Paramacitta Denpasar. Jurnal Intisari Sains Medis, 11(1). DOI: 10.15562/ism.v11i1.208.

Mulawarman., Ariffudin, I. Rahmawati, A,I,N. (2020). Konseling kelompok pendekatan realita (pilihan dan tanggung jawab). Jakarta: kencana.

Mulawarman., \& Sunawan. (2012). Penerapan pendekatan konseling realita untuk mengatasi learned helpness (suatu studi embedded experimental model pada mahasiswa). Intuisi Journal. 4 (1). DOI: 10.15294/intuisi.v4i1.13326.

Nikmarijal, N. (2014). Urgensi peranan keluarga bagi perkembangan self-esteem remaja. Jurnal Konseling dan Pendidikan, 2(2), 19-24. DOI : https://doi.org/10.29210/19800.

Oktavia, F.D. (2016). Efektivitas terapi realitas untuk meningkatkan optimisme pada orang dengan HIV/AIDS (ODHA). (Tesis). Fakultas Psikologi Universitas Katolik Soegijapranata, Semarang.

Prawesti, F. S., \& Dewi, D. K. (2016). Self esteem dan self disclosure pada mahasiswa psikologi pengguna blackberry messenger. Jurnal Psikologi Teori dan Terapan, 7(1), 1-8. http://dx.doi.org/10.26740/jptt.v7n1.p1-8.

Prayitno. \& Amti,. E. (2013). Dasar-dasar bimbingan dan konseling. Jakarta: Rineka Cipta. 
Putri, M.E. (2017). Konseling dengan pendekatan realitas untuk menurunkan kecemasan anak korban kekerasan seksual. Proceeding International Conference.

Refnadi. (2018) Konsep self esteem serta implikasinya pada siswa. Jurnal Pendidikan Indonesia. 4 (1). https://doi.org/10.29210/120182133.

Rohmah, F. A. (2012). Pengaruh pelatihan harga diri terhadap penyesuaian diri pada remaja. Humanitas (Jurnal Psikologi Indonesia), 1(1), 53-63. http://garuda.ristekbrin.go.id/documents/detail/124085.

Rosenfeld D, Anderson J, Ridge D, Asboe D, Catalan J, Collins S, et al. (2015). Social support, mental health, and quality of life among older people living with HIV.

Saam, Z. (2014). Psikologi konseling. Jakarta: Rajawali Pers.

Sharf, R. (2012). Theories of psychotherapy and counseling: Concepts and Case (5th edition). Belmont. CA: Brooks/Cole.

Srisayekti, W. Setiady, D.A. (2015). Harga-diri (self-esteem) terancam dan perilaku menghindar. Jurnal Psikologi. 42(2): 141-156. DOI: 10.22146/jpsi.7169.

Sumini,. Hadisaputro, S. dkk. (2017). Faktor risiko yang berpengaruh terhadap kejadian HIV/AIDS pada pengguna napza suntik. Jurnal Epidemiologi Kesehatan Komunitas. 2(1) 36-45. https://doi.org/10.14710/jekk.v2i1.3993.

Velasco-Martin, J. (2013). Exploring self disclosure in online social network. School Of Information and Library Science.

Vohs, K. D., \& Baumeister, R. F. (2016). Handbook of self-regulation: Research, theory, and applications. Guilford Publications.

WHO. (2018). HIV/AIDS treatment and care. Diunduh dari: http://www.who.int/hiv/topics/treatment/en/ .

Yusuf, S. (2016). Konseling individual konsep dasar \& pendekatan. Bandung: Refika Aditama. 